\title{
Volunteerism among the Academics: The Questions of Motivation and Constraints
}

\section{Asmidar Alias, Kamisah Ariffin \& Nur Asmaliza Mohd Noor}

To Link this Article: http://dx.doi.org/10.6007/IJARBSS/v11-i1/7846

DOI:10.6007/IJARBSS/v11-i1/7846

Received: 04 December 2020, Revised: 30 December 2020, Accepted: 10 January 2021

Published Online: 26 January 2021

In-Text Citation: (Alias et al., 2021)

To Cite this Article: Alias, A., Ariffin, K., \& Noor, N. A. M. (2021). Volunteerism among the Academics: The Questions of Motivation and Constraints. International Journal of Academic Research in Business and Social Sciences, 11(1), 675-689.

\section{Copyright: @ 2021 The Author(s)}

Published by Human Resource Management Academic Research Society (www.hrmars.com)

This article is published under the Creative Commons Attribution (CC BY 4.0) license. Anyone may reproduce, distribute, translate and create derivative works of this article (for both commercial and non-commercial purposes), subject to full attribution to the original publication and authors. The full terms of this license may be seen at: http://creativecommons.org/licences/by/4.0/legalcode

Vol. 11, No. 1, 2021, Pg. 675 - 689

Full Terms \& Conditions of access and use can be found at http://hrmars.com/index.php/pages/detail/publication-ethics 


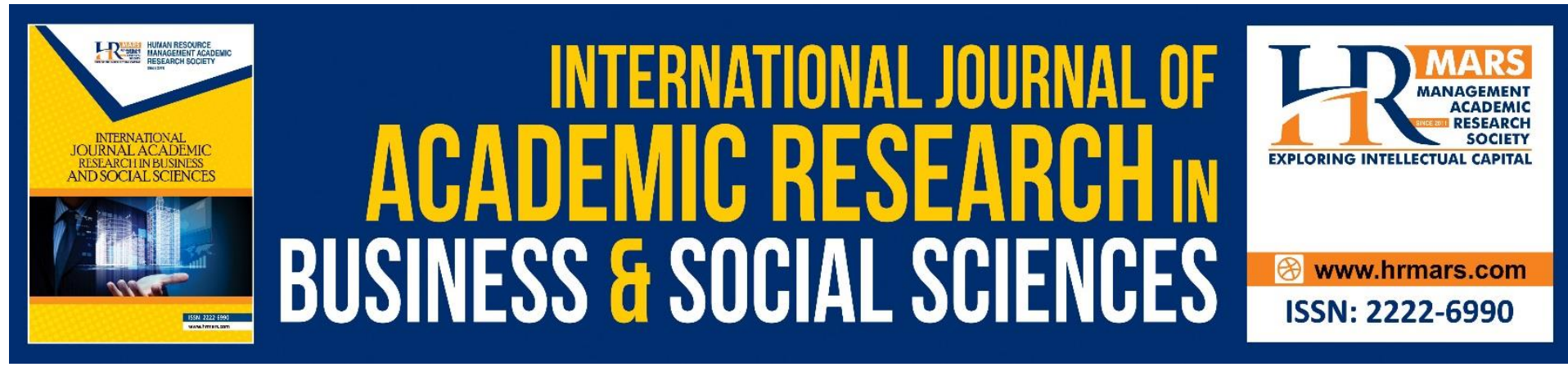

\title{
Volunteerism among the Academics: The Questions of Motivation and Constraints
}

\author{
Asmidar Alias ${ }^{1}$, Kamisah Ariffin² \& Nur Asmaliza Mohd Noor ${ }^{3}$ \\ ${ }^{1,3}$ Faculty of Engineering, Universiti Teknologi MARA Pahang, Malaysia ${ }^{2}$ Academy of \\ Language Studies, Universiti Teknologi MARA Pahang, Malaysia \\ Email: asmidar@uitm.edu.my, nurasmaliza@uitm.edu.my \\ kamisah@uitm.edu.my
}

\begin{abstract}
The University Social Responsibility (USR) is a concept of engaging social works and volunteerism movement within university community in the broad areas of humanity, environment, economic, cultural, education and social development. However, the principle of USR is volunteerism. Different individuals may undertake volunteer activities for different reasons. There can also be various factors that may limit or prevent individuals from volunteering. This study examined the motivational factors and constraints to volunteering among 330 academics in a public university in Malaysia. A survey questionnaire was employed to gauge the volunteer participations under the scope of functional volunteerism and the constraints to participation in the activities. The functional motivations of the participants were analysed using the Volunteer Function Inventory (VFI) under six dimensions: Values, Understanding, Protective, Social, Career and Enhancement, while the constraints to participation in volunteer activities were addressed under three dimensions: Intrapersonal, Interpersonal and Structural. The findings indicate that the Values dimension was the key motivating factor to participation in USR, while the Structure dimension was the major constraint to the participation. Since the reform of Higher Learning Education in Malaysia has considered the University Social Responsibility (USR) as one of the key indexes for the Malaysian universities' rating exercise, it is hoped that the findings may shed some lights on empowering the voluntary acts among the academics to promote beneficial impacts on the local community.
\end{abstract}

Keywords: Volunteerism, Social Responsibility, Academics, Motivational Factors, Constraints

\section{Introduction}

The works relating to social responsibility at universities is broadly known as University Social Responsibility (USR). It is a way of thinking or a guideline for social development to connect with nearby and worldwide network in assorted territories to withstand the social, biological, ecological, specialized, and financial advancement (Chen, Nasongkhla and Donaldson, 2015). Vasilescu, Barna, Epure and Baicu (2010) characterize USR to the need to reinforce urban responsibility and dynamic citizenship. It is tied in with volunteering with moral methodology, 
building up a feeling of common citizenship by empowering the students and the scholastic staff to give social services to local community in diverse areas.

In Malaysia, the reform of the Higher Learning Education welcomes the expansion of the Service Learning Malaysia - University for Society (Sulam) programme to infuse community service as a part of the learning experience. With this reform, the agenda of University Social Responsibility (USR) has been taken seriously by the ministry. USR has become one of the key indexes for the Rating System for Malaysian Education (SETARA) for public universities and the Malaysian Quality Evaluation System (MyQuest) for Private Colleges. The focus is in services and income generation especially on USR and knowledge transfer (Education Malaysia, 2018). This USR ranking will motivate higher learning institutions to be actively involved in social activities to gain positive image and to fulfill the key index criteria (Shaari, Sarip, Rajab and Wan Zakaria, 2018). Recently, consideration has been paid to the job that advanced education can and should play in advancing the improvement of community esteems and obligation (Colby et al., 2000).

However, the principle of USR is volunteerism. This is referred to as "performing a service without compensation for an organization or agency" (Carlo et al., 2005, p. 1296). Many other definitions have also been given to this term but the common themes are contribution to society in one form or another without monetary compensation. What motivates one to be involved in providing social services to the community voluntarily and what constraints him/her from participating in the activities? This paper investigates the motivational factors and constraints to volunteering among academics in a public university in Malaysia. It is hoped that the findings can shed some lights on empowering the voluntary acts among the academics to promote beneficial impacts on the local community.

\section{Literature Review: The Motivation and Constraints to Volunteerism}

Since the principle of USR is volunteerism, it is of paramount importance to understand the factors that can motivate one to be involved in the works. Empirical studies on volunteerism have found that people participated in volunteer works for many reasons along the continuum of altruism to egoism, and of self-interest to others-interest. Several studies have used the functional approach to clearly explain volunteer motivation for most individuals by employing the functional approach. Among the models used were the $2 \times 2$ Model of Seeking and Escaping (Iso-Ahola, 1989), Person-Environment Fit Theory (Sargent \& Sedlacek, 1990), the Psychological Contract (Farmer \& Fedor, 1999), and the Octagon Model of Volunteer Motivation (Yeung, 2004). However, the widely used model and considered the most superior for volunteer motivation has been Clary et al.'s Voluntary Function Inventory (VFI). It is the preferred model for understanding and measuring motivations to volunteer as responses to the VFI scales are strongly related to volunteering activity and possess a high degree of internal consistency and reliability (Burns et al., 2005; Clary and Snyder, 1999).

The Voluntary Function Inventory (VFI) measures six functions of volunteering: Understanding, Social, Values, Protective, Career, and Enhancement. The Understanding function involves a sense of learning and the development of new skills or perspectives. Meanwhile, the Social function addresses the volunteer's participation with friends, or doing work that is viewed as important by the people who matter to him/her. The Values function, on the other hand, relates to an individual putting his/her own beliefs into action to achieve something that he/she perceive as important. The Protective function offers the volunteer to 
cope with inner conflicts or stress. The Career function applies to situations where the individual uses his/her volunteering experience to build career experience or make networking connections. Finally, the Enhancement function deals with what the individual believes for his/her psychological development and personal growth (Clary et al. 1996).

Many studies have utilized this VFI to explore volunteer motivation in different settings. For example, Okun and Schultz (2003) examined volunteer motives across age group. The findings indicate that as age increases, the motivations related to Career and Understanding decreased, while Social functions increased. They also found that age had little and no effect on Enhancement, Protective and Values dimensions of motivation. In the same vein, Burns et al. (2005) compared motivations of students in the marketing classes at five different types of institutions. The study suggested that race is a factor that affects one's likelihood to volunteer. This is in line with earlier studies (Lucas, 1985; Wilson and Musick, 1999). Additionally, Wilson (2005) assessed the level of involvement among volunteers and found that motivation scores increased as participation and involvement increased. The study also reported that those with college degrees were found to spend more hours volunteering than those with less education. Along the same line, Bruyere and Rappe (2007) applied the VFI to volunteers in an environmental setting and added seven new variables to suit this specific form of volunteerism: Help the Environment, Career, User, Learning, Social, Project Organization, and Values and Esteem. They found that Helping the Environment was the most important motivational factor, followed by User, Values and Esteem, Learning, Social, and Project Organization. Career was found to have significantly lower mean scores than the other categories. Widjaja (2010) suggested that the VFI factors are not limited and are strongly dependent on the social and cultural of the nation. He added that the protective function serves to protect the sense of self by decreasing negative impacts related with blame for being luckier than others, or depression. Thus, some might associated this with internal motivation driven by individuals and their spiritual needs, religion, ethics, innate motivation, good will or cultural acceptance.

There can be various factors that may limit or prevent individuals from participating in the activities. Raymore et al. (1993, p.99) posit that "If a factor limits or inhibits participation in a given leisure pursuit, it may then be termed a constraint". Contemporary research on constraints suggests that they are more likely result in modified participation rather than nonparticipation.

There are three types of constraints to volunteerism: 1) Intrapersonal constraints, 2) Interpersonal constraints, 3) Structural constraints. Crawford and Godbey (1987) suggest that Intrapersonal constraints involve psychological states and attributes that interact with leisure preferences. Interpersonal constraints, on the other hand, are those that involve other participants. Structural constraints are intervening factors between preference and participation.

While there have been many studies on motivation to volunteerism, studies on constraints to volunteerism are rather scarce. Most studies have looked into constraints in leisure and recreational activities in general. Shaw et al. (1991) in their study on participation in leisure time activities, for example, found constraints including lack of time because of work, no facilities nearby, lack of time because of other leisure activities, low energy, requires too much 
self-discipline, costs too much, injury or handicap, ill health, lack of necessary skills, available facilities are inadequate, and no leaders available. However, Shaw et al. suggested that the constraints themselves did not act directly as barriers to participation but the individual's perception on how the constraints may affect their activities.

Jackson et al. (1993) found that participations to activities may involve individuals negotiating through the constraints. They found that there is a hierarchical relationship between the three levels of constraints. Based on Crawford et al.'s (1991) Model of Leisure Constraints, Jackson et al. suggested that individuals will first be confronted with intrapersonal constraints. If they are able to negotiate through this level of constraints, they will proceed to interpersonal constraints. If these are successfully negotiated, they will continue to negotiate with the structural constraints. If all three levels are successfully negotiated, they will participate in the activity and vice versa.

\section{The Study}

The main objectives of this study were to examine the motives and constraints to volunteering among the academics. Specifically, it looks into the motivational factors of academics to volunteer in various capacities and to explore factors that may act as constraints to their participation in the activities. Thus, this can be expressed by the following research questions:

i. What motivates academics in participating in volunteer activities?

ii. What constraints academics from participating in volunteer activities?

\section{Data Collection and Analysis}

The study involved academics in a public university in Malaysia who had participated in USR activities. An invitation to take part in the survey was extended to the academics through an electronic questionnaire survey posted via the university's emailing system. The survey was made available for one month. Respondents were allowed to submit multiple responses to the survey during the period of availability but only the latest response by the respondent would be taken into account. 330 academics voluntarily responded to the survey with the distribution of 88 male and 242 of female respondents.

The questionnaire was adapted from Clary \& Snyder's (1999) and Burns et al.'s (2005) tools that examined the volunteer participations under the scope of functional volunteerism and the constraints to participation in the activities. The whole questionnaire consisted of four sections. The first section gauged the demographic background of the participants. The second section looked into the participants' background of volunteerism which included the scope of volunteerism, the types of volunteer activities they had been involved in, and the frequency of participation. The third section examines the functional motivations of the participants using the Volunteer Function Inventory (VFI) under six dimensions: Values, Understanding, Protective, Social, Career and Enhancement. It contained 34 statements that were rated on a three Lickert-scale: Not at all Important, Important and Very Important. The last section addressed the constraints to participation in volunteer activities under three dimensions: Intrapersonal, Interpersonal and Structural. It contained 16 constraint statements that were rated on a three Lickert scale: Not at all Influential, Influential and Very Influential. 
The data were treated quantitatively. The data on the demographic background of the participants and the background of their USR participations were analysed based on the frequency counts. As for the motivation and constraint to participation, factor analysis was employed to gauge the motivation dimensions on the VFI items and Leisure constraint Model for constraint dimensions. Besides, the analysis using Relative Importance Index was also constructed to identify the dimensions that have the most influence on the USR participation among the academics.

\section{Findings and Discussion}

\section{Demographic Background of Participants}

Of the 330 participants, $3.6 \%$ were between $22-30$ years old, $41.8 \%$ were $31-40$ years old, $36.1 \%$ were $41-50$ years old and $18.5 \%$ were more than 50 years old. It is very important to note that nearly $80 \%$ of the respondents were between $31-50$ years old. This group of academics mostly would already have been stable in the career. This is reflected in the analysis where there were $22.1 \%$ lecturers, $62.7 \%$ senior lecturers, $11.5 \%$ associate professors and $2.1 \%$ professors in this group.

The age and career stability factors posed a significant impact on the frequency of their involvement in volunteering activities. The data indicate that only $18.8 \%$ of this group of academics was involved in more than one activity in a month. The other $8.2 \%$ were involved only once a month, $15.5 \%$ once in every 3 months, $34.2 \%$ once for every 6 months and $33.3 \%$ once in a year. Such findings may relate to the benefits that volunteering activities give to their career prospect. As volunteering activities is considered as one of the criteria for promotional exercise in the university, it can be inferred that those who are at the higher ladder of their career, i.e senior lecturers, associate professors and professors, may have less motivation to get involved in the activities. High frequency of involvement in the volunteering activities might not benefit them in terms of promotion if they felt that they had already reached the highest possible peak of their career.

Although the frequency of involvement might be low among this group of respondents, the motivation and constraints to volunteering works might differ individually. The next section examines these aspects to volunteerism among the respondents.

\section{Motivation to Volunteerism}

The Volunteer Function Inventory (VFI) investigated the respondents' motivation under six dimensions: Values, Understanding, Protective, Enhancement, Career and Social. Table 1 depicts the motivation factors according to the VFI among the respondents.

Table 1: Motivation to Volunteerism according to VFI Dimension

\begin{tabular}{lll}
\hline No & Volunteer Function Inventory Dimension & Mean \\
\hline 1 & Values & 3.56 \\
\hline 2 & Understanding & 2.84 \\
\hline 3 & Protective & 3.07 \\
\hline 4 & Enhancement & 3.20 \\
\hline 5 & Career & 2.62 \\
\hline 6 & Social & 2.83 \\
\hline
\end{tabular}


As can be seen from the table, the highest mean according to VFI was Values (mean score=3.56) while the lowest was Career (mean score $=2.62$ ). Regardless of the individuals' frequency of involvement, the finding indicate that having the humanitarian concern for others was more important for this group of respondents compared to the expectation on the reward related to career enhancement. As mentioned earlier, this may due to the stability of their career that made them appreciate the values of humanity more compared to career reward. Thus, this finding is not conclusive as the results may be different for different groups of respondents.

Table 2 shows the detailed assessment of each of the VFI dimensions. The score on each of the questionnaire statements were able to indicate respondents' motivation orientation towards volunteering activities.

Table 2: Motivation to Volunteerism based on Questionnaire statement

\begin{tabular}{llc}
\hline \multicolumn{2}{l}{ Volunteer Function Inventory Dimension: Values } & \\
\hline No & Statement & Mean \\
\hline 1 & I feel it is important to help others. & 3.81 \\
\hline 2 & I am genuinely concerned about the particular group I am serving. & 3.64 \\
\hline 3 & I am concerned with those less fortunate than myself. & 3.69 \\
\hline 4 & Volunteering allows me to gain a new perspective on things. & 3.70 \\
\hline 5 & I feel compassion towards people in need. & 3.68 \\
\hline 6 & I can explore my own strengths. & 3.51 \\
\hline 7 & I can learn how to deal with a variety of people. & 3.55 \\
\hline 8 & I can learn more about the cause for which I am working. & 3.49 \\
\hline 9 & Volunteering is a way for me to help the natural environment. & 3.44 \\
\hline 10 & Volunteering is part of religious deeds & 3.56 \\
\hline 11 & Volunteering strengthens my relationship to my religion & 3.55 \\
\hline 12 & I volunteered because my religion tells me to do so & 3.34 \\
\hline 13 & I feel volunteering is a religious duty. & 3.45 \\
\hline 14 & It is a way to attain reward from God & 3.47 \\
\hline Volunteer Function Inventory Dimension: Understanding & \\
\hline No & Statement & Mean \\
\hline 1 & No matter how bad I've been feeling, volunteering helps me to forget & 2.80 \\
\hline & about it. & \\
\hline 2 & Doing volunteer work relieves me of some of the guilt over being more & 2.92 \\
\hline & fortunate than others. & 2.72 \\
\hline 3 & Volunteering makes me feel important. & 3.60 \\
\hline Volunteer Function Inventory Dimension: Protective & 3.20 \\
\hline No & Statement & \\
\hline 1 & Volunteering is a good escape from my own troubles. \\
\hline 2 & Volunteering helps me to work through my own personal problems. \\
\hline 3 & I can do something for a cause that is important to me. & 2.78 \\
\hline 4 & Volunteering makes me feel better about myself. \\
\hline Volunteer Function Inventory Dimension: Enhancement & 2.98 \\
\hline No & Statement & \\
\hline 1 & Volunteering makes me feel needed. & \\
\hline & & \\
\hline
\end{tabular}




\begin{tabular}{llc}
2 & Volunteering lets me learn things through direct, hand-on experience. & 3.63 \\
\hline 3 & Volunteering increases my self-esteem. & 3.06 \\
\hline 4 & Volunteering is a way to make new friends. & 3.14 \\
\hline \multicolumn{2}{l}{ Volunteer Function Inventory Dimension: Career } & Mean \\
\hline No & Statement & 2.72 \\
\hline 1 & I can make new contacts that might help my business or career. & 2.61 \\
\hline 2 & Volunteering experiences will look good on my resume. & 2.55 \\
\hline 3 & Volunteering allows me to explore different career options. & 2.60 \\
\hline 4 & Volunteering will help me to succeed in my chosen profession. \\
\hline Volunteer Function Inventory Dimension: Social & Mean \\
\hline No & Statement & 2.45 \\
\hline 1 & People I'm close to want me to volunteer. & 2.77 \\
\hline 2 & Others with whom I am close place a high value on community service. & 2.88 \\
\hline 3 & My friends volunteer. & 2.98 \\
\hline 4 & Volunteering is an important activity to the people I know best. & 3.07 \\
\hline 5 & People I know share an interest in community service. &
\end{tabular}

As can be seen in Table 2, the Value dimension indicates that the majority of the respondents believed on the importance of helping others (mean score= 3.81). Thus, they strongly felt that by involving in volunteering works, they would be able to help others and gain new perspectives on things. This can be seen in the higher scores in statements 3 (mean score=3.69), 5 (mean score=3.68), and 2 (mean score=3.64). Besides helping people, the respondents also believed that they would be able to help natural environment (mean score=3.44). This is in accordance to Graefe et al.'s (2000) study which identified that the strongest motives to volunteering were helping others and expanding one's own perspective on an issue. Latting (1990) also agreed that the Values motive was a booster and motivation factor to do volunteer. The Value dimension also places the importance of religion as the motivational factors to the respondents' volunteering activities. Being 'part of religious deeds', to 'strengthen relationship to religion' and as a 'way to attain reward from God' received high scores among the items in the VFI.

As for the Understanding dimension, the highest score was on the feeling of relief of guilt that the respondents had over being fortunate than others (statement 2, mean score=2.92). Volunteering made them feel important as they could contribute to those who were not as unfortunate as them. In addition, participating in volunteering activities also seemed to be some kind of escapism for any bad feelings that the respondents might have. This can be seen in statement 1 (mean score=2.80). This is in line with Astin and Sax's (1998) study that found the respondents were strongly committed to helping others and serving their communities.

The Protective dimension relates to how the respondents tried to protecting their negative features in their self. For example, they believed that by participating in volunteering works, they could do something for a reason that is important to them (statement 3, mean score $=3.60$ ) and this made them feel good about themselves (statement 4, mean score=3.20). However, the respondents did not really believe that volunteering could help them solve their own personal problems or troubles. This can be seen in the lower scores in statements 1 and 2 (mean scores $=2.75$ and 2.72 respectively). 
The Enhancement dimension sees those who participate in volunteering activities as having the advantages of developing their knowledge and social skills. The respondents in this study believed that the activities had enabled them to learn things through direct and hands-on experience (mean score=3.63), and increased their self-esteem (mean score $=3.06$ ) and social circles (mean score=3.14). However, the respondents did not really feel that they were needed (mean score $=2.98$ ) as they believed that other volunteers would also be able to contribute like them.

The Career dimension of the VFI seemed to have lower scores among the other dimensions. The mean scores of all the statements that relate to the career enhancement and career option were only between 2.55 and 2.72. This contradicts with Kamaruddin et al.'s (2000) study which found that career factor as an important motivation in doing volunteering activities. Such conflicting finding, as mentioned earlier might relate to the age and career stability factors of the respondents. Thus, they might have less of a need to volunteer in order to enhance their resumes, build social networks, or explore new careers.

The Social dimension shows that volunteering works can be influenced by people around you. The analysis indicates that the respondents in this study were motivated to take part in the volunteering activities because of their social contacts. They might join because their friends participated in the activities, or because they felt that other people would like them to participate as well. This supports Freeman's (1997) finding that respondents would join as volunteer if they had been asked to do so rather than joining their own.

The analysis of Relative Importance Index for the motivation factors is shown in Table 3. It shows the ranking of all statements from the VFI.

Table 3: Relative Importance Index for Motivation Factor

\begin{tabular}{lllc}
\hline No & Motivation Statement & RII & Rank \\
\hline 1 & $\begin{array}{l}\text { Doing volunteer work relieves me of some of the guilt over being } \\
\text { more fortunate than others. }\end{array}$ & 1.4030 & 1 \\
\hline 2 & I feel it is important to help others. & 0.9523 & 2 \\
\hline 3 & Volunteering allows me to gain a new perspective on things. & 0.9250 & 3 \\
\hline 4 & I am concerned with those less fortunate than myself. & 0.9220 & 4 \\
\hline 5 & I feel compassion towards people in need. & 0.9205 & 5 \\
\hline 6 & I am genuinely concerned about the particular group I am serving. & 0.9091 & 6 \\
\hline 7 & Volunteering lets me learn things through direct, hand-on & 0.9068 & 7 \\
& experience. & & \\
\hline 8 & I can do something for a cause that is important to me. & 0.8992 & 8 \\
\hline 9 & Volunteering is part of religious deeds & 0.8909 & 9 \\
\hline 10 & I can learn how to deal with a variety of people. & 0.8871 & 10 \\
\hline 11 & Volunteering strengthens my relationship to my religion & 0.8864 & 11 \\
\hline 12 & I can explore my own strengths. & 0.8773 & 12 \\
\hline 13 & I can learn more about the cause for which I am working. & 0.8735 & 13 \\
\hline 14 & It is a way to attain reward from God & 0.8667 & 14 \\
\hline 15 & I feel volunteering is a religious duty. & 0.8621 & 15 \\
\hline 16 & Volunteering is a way for me to help the natural environment. & 0.8606 & 16 \\
\hline
\end{tabular}




\begin{tabular}{llll}
\hline 17 & I volunteered because my religion tells me to do so & 0.8356 & 17 \\
\hline 18 & Volunteering makes me feel better about myself. & 0.8008 & 18 \\
\hline 19 & Volunteering is a way to make new friends. & 0.7848 & 19 \\
\hline 20 & People I know share an interest in community service. & 0.7674 & 20 \\
\hline 21 & Volunteering increases my self-esteem. & 0.7644 & 21 \\
\hline 22 & Volunteering is an important activity to the people I know best. & 0.7455 & 22 \\
\hline 23 & Volunteering makes me feel needed. & 0.7447 & 23 \\
\hline 24 & My friends volunteer & 0.7197 & 24 \\
\hline 25 & $\begin{array}{l}\text { No matter how bad I've been feeling, volunteering helps me to } \\
\text { forget about it. }\end{array}$ & 0.7008 & 25 \\
\hline 26 & Volunteering makes me feel important. & 0.6939 & 26 \\
\hline 27 & $\begin{array}{l}\text { Others with whom I am close place a high value on community } \\
\text { service. }\end{array}$ & 0.6917 & 27 \\
\hline 28 & Volunteering is a good escape from my own troubles. & 0.6886 & 28 \\
\hline 29 & $\begin{array}{l}\text { Volunteering helps me to work through my own personal } \\
\text { problems. }\end{array}$ & 0.6811 & 29 \\
\hline 30 & I can make new contacts that might help my business or career. & 0.6803 & 30 \\
\hline 31 & Volunteering experiences will look good on my resume. & 0.6515 & 31 \\
\hline 32 & Volunteering will help me to succeed in my chosen profession. & 0.6492 & 32 \\
\hline 33 & Volunteering allows me to explore different career options. & 0.6379 & 33 \\
\hline 34 & People I'm close to want me to volunteer. & 0.6136 & 34 \\
\hline & & & \\
\hline
\end{tabular}

\section{Constraints to Volunteerism}

The constraints variables in this study were categorized under three dimensions of the Leisure Constraint Model: Structure, Intrapersonal and Interpersonal. The analysis is shown in Table 4 below.

Table 4: Constraints to Volunteerism

\begin{tabular}{lll}
\hline No & Volunteer Function Inventory Dimension & Mean \\
\hline 1 & Structure & 1.94 \\
\hline 2 & Intrapersonal & 1.90 \\
\hline 3 & Interpersonal & 1.77 \\
\hline
\end{tabular}

As can be seen from Table 4, the highest constraints faced by the respondents were under the Structure dimension (mean score=1.94). This is followed by constraints under the Intrapersonal dimension (mean score $=1.90$ ) and Interpersonal dimension (mean score $=1.77$ ).

Table 5 shows the detailed assessment of each of the constraints dimensions. The score on each of the questionnaire statements were able to indicate constraints that could hinder the respondents from participating in volunteering activities. 
Table 5: Constraints to Volunteering Activities

\begin{tabular}{llc}
\hline \multicolumn{2}{l}{ Leisure Constraint Model: Structure } & \\
\hline No & Statement & Mean \\
\hline 1 & I do not need the merit (of volunteering) for my work & 1.83 \\
\hline 2 & I do not have transportation to volunteer sites & 1.64 \\
\hline 3 & I do not have the necessary skills & 1.74 \\
\hline 4 & I have no time to volunteer & 1.99 \\
\hline 5 & I do not have enough energy to volunteer & 2.13 \\
\hline 6 & I have a limited budget & 2.33 \\
\hline Leisure Constraint Model: Intrapersonal & Mean \\
\hline No & Statement & 1.64 \\
\hline 1 & I do not feel safe at volunteer sites & 1.57 \\
\hline 2 & I think it will negatively affect my work & 2.48 \\
\hline 3 & I have too many other commitments & 1.62 \\
\hline 4 & I have an injury, handicap or ill health & 2.21 \\
\hline 5 & I am unaware of opportunities to volunteer & \\
\hline Leisure Constraint Model: Interpersonal & Mean \\
\hline No & Statement & 1.81 \\
\hline 1 & I have no one to volunteer with & 1.64 \\
\hline 2 & My family does not volunteer & 1.69 \\
\hline 3 & My friends do not volunteer & 1.72 \\
\hline 4 & No one has asked me to volunteer & 1.99 \\
\hline 5 & I do not know anyone that volunteers & \\
\hline & & \\
\hline
\end{tabular}

The analysis indicates that the Structure constraints hindered the respondents from participating actively in the volunteering activities. The respondents reported constraints of budget (mean score=2.33), energy (mean score=2.13) and time (mean score=1.99) as the factors that limit their participation. This supports earlier studies that reported the most common objection to volunteering was that it consumed time and energy (Astin \& Sax, 1998). Gage (2009) and Martinez and McMullin (2004) also found that structural constraints were the most influential decision for the respondents not to be active in volunteering works. Other constraints found in the present study include not having the necessary skills needed for the activities and not having facilities like transportation. This supports earlier findings by Shaw et al. (1991) that constraints to participation in volunteering services were lack of time because of work, no facilities nearby and low energy. Another constraints that exerts influence on volunteering is also related to the career stability of the respondents, that they did not need the merit of volunteering for their work (mean score=1.83)

It was also reported that constraints under the Intrapersonal dimension were the reasons for inactive participation among the respondents. The analysis shows that competing commitments had the greatest effect on the decision not to volunteer. This is in line with Martinez and McMullin's (2004) finding that suggested commitments could influence decision not to participate in the volunteering works. Other constraints were related to personal problem like unawareness of the opportunities to volunteer (mean score $=2.21$ ), not feeling safe at the sites (mean score=1.64), having injury and health problems (mean score $=1.62$ ), and thinking that the volunteering activities would negatively affect their work 
(mean score=1.57). Forster et al. (2015) in their study also presented the major constraints in doing volunteering activities which included unmeet respondents' expectations and insufficient opportunity.

The Interpersonal constraints involve social support from people around them. The analysis shows that the respondents' participation in the volunteering activities was determined by the involvement of family members and friends in the activities. This is shown in statements $1,2,3,4$ and 5 (mean scores=1.81, 1.64, 1.69, 1.72 and 1.99 respectively), in the Interpersonal constraints dimension. This is in line with previous studies that some people desired a social setting in which to interact with other people, thus needed the support of people around them in order to volunteer (Wickham and Graefe, 1998).

The analysis of Relative Importance Index for the constraint factors is shown in Table 6. It shows the ranking of all statements from the constraint variables.

Table 6: Relative Importance Index for Constraint Factors

\begin{tabular}{llcc}
\hline No & Constraint Statement & RII & Rank \\
\hline 1 & I have too many other commitments. & 0.620 & 1 \\
\hline 2 & I have a limited budget. & 0.583 & 2 \\
\hline 3 & I am unaware of opportunities to volunteer. & 0.553 & 3 \\
\hline 4 & I do not have enough energy to volunteer. & 0.533 & 4 \\
\hline 5 & I do not know anyone that volunteers & 0.498 & 5 \\
\hline 6 & I have no time to volunteer. & 0.498 & 6 \\
\hline 7 & I do not need the merit (of volunteering) for my work. & 0.458 & 7 \\
\hline 8 & I have no one to volunteer with. & 0.452 & 8 \\
\hline 9 & I do not have the necessary skills. & 0.434 & 9 \\
\hline 10 & No one has asked me to volunteer. & 0.430 & 10 \\
\hline 11 & My friends do not volunteer. & 0.423 & 11 \\
\hline 12 & I do not feel safe at volunteer sites. & 0.411 & 12 \\
\hline 13 & I do not have transportation to volunteer sites. & 0.411 & 13 \\
\hline 14 & My family does not volunteer. & 0.410 & 14 \\
\hline 15 & I have an injury, handicap, or ill health. & 0.404 & 15 \\
\hline 16 & I think it will negatively affect my work. & 0.393 & 16 \\
\hline
\end{tabular}

\section{Conclusion}

As universities have expanding focus to become socially integrated with local and global community, their social character has also changed profoundly. They acknowled ge 'their open obligation regarding advancing social value and a comprehensive society' (EUA, 2007, p. 2). Thus, the social responsibility works are evolving in every aspect in these higher learning institutions. However, as mentioned earlier, the social responsibility works are based on volunteerism. In this study, the Volunteer Function Inventory and the Three-Dimensional constraints framework have shown the motivations and constraints to volunteerism among the academics. The analysis has shown that both motivations and constraints exert their influence in determining whether or not an individual will volunteer. As attested by Burns et al. (2005), individual's motivation to volunteer is a better predictor of future behaviors than 
current volunteer activities since the extent of one's current behaviors is often influenced by the amount of time an individual has for volunteering.

While volunteerism may be a personal motivation, at times, especially if it is a compulsory requirement of the job, volunteer activities are often undertaken by obligation, not free will. Thus, in encouraging USR among the academics, institutions should also consider the academics' personal needs while accomplishing the goals of USR. One of the ways is by getting recognition from the public and providing volunteers with other social benefits that can satisfy their Values motive in doing the voluntary activities. Volunteers participate in various programs to give back to their communities, help a cause, or build social networks. Thus, by giving them public recognition and providing social benefits can create more incentive to overcome Interpersonal constraint. As put forward by Ryan et al. (2001), people may initially take part in volunteer programs for altruistic reasons, but they are more likely to stay active if they perceive other benefits (such as social benefits) as well.

\section{References}

Alzyoud, S. A., \& Bani-Hani, K. (2015). Social responsibility in Higher Education Institutions: Application case from the Middle East. European Scientific Journal, Vol.11, No.8, pp 122129

Astin, A. W., \& Sax, L. J. (1998) How undergraduates are affected by service participation, Journal of College Student Development, 39(3), pp. 251-263.

Bruyere, B., \& Rappe, S. (2007) Identifying the motivations of environmental volunteers. Journal of Environmental Planning and Management, 50(4), pp. 503-516

Carlo, G., Okun, M. A., Knight, G. P., \& de Guzman, M. T. (2005) The interplay of traits and motives on volunteering: Agreeableness, extraversion and prosocial value motivation, Personality and Individual Differences, 38, pp. 1293-1305. Chen, Nasongkhla and Donaldson, 2015.

Clary, E. G., Snyder, M., \& Stukas, A. A. (1996) Volunteers' Motivations: Findings from a national survey. Nonprofit and Voluntary Sector Quarterly, 25(4), pp. 485-505.

Colby, A., Ehrlich, T., Beaumont, E., Rosner, J., and Stephens, J. (2000). 'Higher Education and the Development of Civic Responsibility', in Ehrlich, T. (ed.), Civic Responsibility and Higher Education,Phoenix, AZ: American Council on Education / Oryx Press: Series on Higher Education, 2000, pp. xxi-xliii

Crawford, D., \& Godbey, G. (1987) Reconceptualizing barriers to family leisure. Leisure Sciences, 9, pp. 119-127.

Dima, A. M., Vasilache, S., Ghinea, V., and Agoston, S. (2015). A Model of Academic Social Responsibility. Transylvanian Review of Administrative Sciences, N0. 38 E/2013, pp. 2243.

https://www.researchgate.net/publication/281320388_A_model_of_academic_social _responsibility

Education Malaysia. (n.d.) SETARA Rating. https://educationmalaysia.gov.my/setara-rating/

European University Association (EUA). (2007). The Lisbon Declaration Europe's Universities beyond 2010: Diversity with a Common Purpose, 2007, [Online] available at http://www.aic.lv/bolona/Bologna/London_conf/Lisbon_declaration.pdf.

Farmer, S. M., \& Fedor, D. B. (1999) Volunteer participation and withdrawal: A psychological contract perspective on the role of expectations and organizational support. Nonprofit Management \& Leadership, 9(4), pp. 349-367. 
Freeman, R. B. (1996). Working for nothing; the supply of volunteer labour. National bureau of Economic research 5543(1), pp.1- 41

Forster, D. J., Archer, J., \& Tajin, R. T. (2015). Volunteering within Initial Teacher Education: Factors that Boost and Block Participation. Australian Journal of Teacher Education Volume 40 Issue 11, pp 169-184.

Gage, R. L. (2009). Volunteer Motivations and Constraints Among Undergraduate College Students. Master Dissertation University of Florida.

Giacalone, R. A., and Thompson, K. R. (2006). Business Ethics and Social Responsibility Education: Shifting the Worldview, 2006. Academy of Management Learning \& Education, vol. 5, no. 3, pp. 266-277.

Graefe, A. R., Thapa, B., Confer, J. J., \& Absher, J. D. (2000) Relationships between trip motivations and selected variables among Allegheny National Forest visitors. In: USDA Forest Service Proceedings, 15(4), pp. 107-112.

Iso-Ahola, S. E. (1989) Motivation for Leisure, in: E.L. Jackson \& T.L. Burton (Eds) Understanding Leisure and Recreation: Mapping the Past Charting the Future (State College, PA, R.A. Venture Publishing).

Jackson, E. L., Crawford, D. W., \& Godbey, G. (1993) Negotiation of leisure constraints. Leisure Sciences, 15, pp. 1-11.

Kamarudin, M. K., Wong, N. Y. J., Abdul Rashid, A., Devaraj, N. K., \&Shamsuddin, N. H. (2020). Factors Associated with motivation to volunteer among lecturers in faculty of medicine and health science, Universiti Putra Malaysia. International Journal of Human and Health Science Vol 4, No 2, pp: 136-141.

Latting, J. K. (1990). Motivational Differences Between Black and White Volunteers. Nonprofit and Voluntary Sector Quarterly 19(2), pp. 121-36.

Lucas, J. S. (1985) The social participation of blacks: A proposed synthesis of two competing theories. Sociological Inquiry, 55(1), pp. 97-108.

Marinescu, P., Toma, S. G., \& Constantin, I. (2010). 'Social Responsibility at the Academic Level. Study Case: The University of Bucharest', 2010. Studies and Scientific Researches - Economic Edition, no. 15, pp. 404-410

Martinez, T. A., \& McMullin, S. L. (2004) Factors affecting decisions to volunteer in nongovernmental organizations. Environment and Behavior, 36(1), pp. 112-126.

Laird, N. T. F., Engberg, M. E., \& Hurtado, S. (2005). Modeling Accentuation Effects: Enrolling in a Diversity Course and the Importance of Social Action Engagement., The Journal of Higher Education, vol. 76, no. 4, pp. 448-476.

Okun, M. A., \& Schultz, A. (2003) Age and motives for volunteering: Testing hypotheses derived from Socioemotional Selectivity Theory, Psychology and Aging, 18(2), pp. 231239.

Omoto, A.M. \& Snyder, M. (2002). Considerations of Community: The Context and Process of Volunteerism. American Behavioral Scientist 45 (5), pp.846-67.

Shaari, R., Sarip, A., Rajab, A., and Wan Zakaria,W. A. (2018). The Impact of University Social Responsibility Towards Producing Good Citizenship: Evidence From Malaysia. International Journal of Organizational Leadership 7,pp. 374-382

Raymore, L., Godbey, G., Crawford, D., \& Von Eye, A. (1993) Nature and process of leisure constraints: An empirical test. Leisure Sciences, 15, pp. 99-113.

Ryan, R. L., Kaplan, R., \& Grese, R. E. (2001) Predicting volunteer commitment in environmental stewardship programmes. Journal of Environmental Planning and Management, 44(5), pp. 629-648. 
Sergent, M. T., \& Sedlacek, W. E. (1990) Volunteer motivations across student organizations: A test of Person-Environment Fit theory. Journal of College Student Development, 31, pp. 255-261.

Shaw, S. M., Bonen, A., \& McCabe, J. F. (1991) Do more constraints mean less leisure? Examining the relationship between constraints and participation, Leisure Research, 23(4), pp. 286-300.

UNESCO. (1998). Higher Education in the Twenty-first Century: Vision and Action. World Conference on Higher Education. UNESCO Paris. Retrieved on November 20, 2019. https://unesdoc.unesco.org/ark:/48223/pf0000116345

Vasilescu, R., Barna, C., Epure, M., \& Baicu, C. (2010). Developing University Social Responsibility: A Model for the Challenges of the New Civil Society. Procedia Social and Behavioral Sciences, vol. 2, pp. 4177-4182.

Wickham, T. D., \& Graefe, A. (1998) Motivation to volunteer at Shaver's Creek Environmental Center, in Proceedings of the 1998 Northeast Recreation Research Symposium, pp. 2327.

Widjaja, E. (2010). Motivation Behind Volunteerism. CMC Senior Theses. 4. http://scholarship.claremont.edu/cnc_theses/4. Claremont McKenna College, Claremont, United State.

Wilson, R. S. (2005) Motivational factors and decisions to volunteer in the Florida Park Service, Unpublished Master Thesis (Gainesville, FL, University of Florida).

Wilson, J., \& Musick, M. (1999) The effects of volunteering on the volunteer. Law and Contemporary Problems, 62(4), pp. 141-168.

Yeung, A. B. (2004) The octagon model of volunteer motivation: Results of a phenomenological analysis. Volantes: International Journal of Voluntary and Nonprofit Organizations, 15(1), pp. 21-46. 